\title{
Impact of FDI Inflow on Average Wage and Employment in Serbia
}

DOI: 10.7595/management.fon.2019.0007

\begin{abstract}
:
Research question: This research comes to examine the impact of FDI inflow on average wage and on employment in Serbia in the period 2005-2017. Motivation: FDI tendentiously increases the economic growth rates, taking into consideration the fact that developed economies benefit from FDI because their local institutions are more productive, while developing countries benefit from "pieces" of FDI, i.e., dissemination of technology and rarely evoke some relevant progress in economic growth. Despite the growing research in the FDI field, the scientific literature on average wage and employment in relation to FDI Inflow in Serbia is limited, which is the motivation to conduct this research. Idea: Therefore, the aim of this research is to estimate the relationship between FDI Inflow and average wage and employment. Data: The data are obtained from the official sites of the National Bank of Serbia and from the Statistical Office of Serbia. Tools: The methodology used is the multiple Linear Regression Model, applying the IBM SPSS software, in order to identify the impact of FDI Inflow on average wage and on employment using time lags. Findings: The results prove the absence of significant impact of FDI inflow on average wage and on employment within the country. The highest positive impact of FDI inflow appears to be in the year the inflow occurs for average wage, and in the second year of FDI inflow performance for employment. Contribution: This paper contributes to the awareness of low impact of FDI inflow on average wage and on employment in Serbia. Moreover, this research covers the gap in the literature in the field of FDI inflow in relation to average wage and employment within the country.
\end{abstract}

Keywords: average wage, economic growth, employment rate, FDI inflow spillovers, regression

JEL classification: C10, F16, G10, Y10

\section{Introduction}

Based on the definition by UNCTAD (2007), "FDI inflow comprises capital provided by foreign direct investor to a foreign affiliate, or capital received by a foreign direct investor from a foreign affiliate." In 2016, developing countries attracted one third of the global FDI inflow, while global FDI got down by 2 per cent (UNCTAD, 2017a). According to the UNCTAD (2013), the shapes of FDI are as follows: 1) Horizontal (greenfield, acquisitions), 2) Vertical (adaptation of production for domestic market, marketing) and 3) Mixed (mix of different activities to decrease risks).

The globalization strategy is expected to be a motivation for a wave of acquisitions and mergers of companies in the future in order to realize economic interests, such as economy of shape, rationalization of industries with over-capacities, etc. It is not a simple task for governments to attract FDI, let alone for those in developing countries. While it is difficult for many countries to attract foreign investments, BRICS is the leader in investing in developing countries (UNCTAD, 2017b; Peric, 2016), the fact that may send the message that unions may create a difference in FDI attraction performance. FDI have registered a significant fluctuation over the world in the last few decades. In all countries, FDI inflow corrects the life cycle of the business activities, especially bringing changes in technology and human capital, and vice versa, the level of education and labour skills are required to attract FDI.

The benefits of FDI appear differ worldwide. What the empirical evidence suggests is that spillover effects of FDI are different, based on the level of development of a certain country: for developing countries these 
are technology and knowledge, while for developed countries these are an increase in average wage and in employment (Javorcik, 2015). On the basis of this statement, in case of Serbia, one could expect that the spillover effects of FDI by this research would be the common to ones in developing countries.

FDI affect the increase in total investments of the country, which is difficult to attract because of their sensitivity to the investment climate of the country. Domestic companies in Serbia have to deal with bankruptcy and survival, and FDI inflow seems to be the best solution. For domestic companies, though, it is desirable to be financed from the national savings. For this reason, Serbia needs to convince the potential investor by offering a good investment climate. Even if the motive of the foreign investor is to achieve profits, usually the foreign investor does face risks, but not necessarily decides to invest in the risky environment which means a high level of corruption and undeveloped infrastructure, unless the investor wishes to reenable the industrial or town existing infrastructure.

The Serbian government is actually searching for the investor for building the underground railway system, as it was the case for Savamala, Zastava, Telekom Srbija, Pivara Zaječar, and many other investments (Ministry of Economy, 2018). The aims of both investor and user are the import substitution opportunities, avoidance of barriers (custom, bureaucracy), achieving economies of scale as well as economic dominance and strategic businesses. As far as the risks and benefits are concerned, there is to remind that the acquisition (privatization) of the Mobtel Company (local mobile phone operator) by the Norwegian Telenor for $€ 1.5$ billion in 2006 produced a high profit (Telenor Group, 2006). According to data provided by the National Bank of Serbia (2017) as regards the structure of FDI inflow in Serbia by economic activities, the highest level of FDI inflow has been made in financial intermediation (banks mostly), manufacturing, commerce and real estate and renting (in regressive order).

Serbia has both advantages and disadvantages in the economic environment as regards attracting FDI. Among advantages are identified: relative macroeconomic stability in the last 10-15 years with an increasing positive trend, human resources because of the high quality educated staff and low cost skilled labour, privatized banking sector with low interest rates, liberalized system of tariffs especially with the countries of the European Union (EU), geographically favourable position, significant achievements in the fiscal accommodation, sustainable GDP growth, adjustments of the structure of employment for needs of foreign investors, etc. (Bartels, 2009; Radojevic, Sarac, Radovanovic, \& Stanisic, 2015). Stankov, Markov and Milosevic (2015) stress that the most attractive economic sectors as investment destinations for foreign investors are manufacturing and wholesale and retail, emphasizing therefore the importance of corruption reduction.

On the other hand, the disadvantages are: inadequate economic environment and structure, high level of corruption, administrative barriers, lack of transparency of the institutions and their procedures, poor market reputation, poor infrastructure, limited liquidity, poor profitability, poor functioning of the rule of law, low level of economic development and political stability, decrease in population, a country still in the transition process, delay in accessing the EU and the WTO, etc. (Bartels, 2009; Peric \& Filipovic, 2018).

The main scope of this research is to contribute to the awareness about the impact of the FDI inflow on average wage and on employment. The objective of this research is to investigate the impact of the FDI inflow on average wage and on employment in Serbia in the period from 2005 to 2017.

This paper is organized in 5 sections. The present section brings the definitions of FDI and their main characteristics. The second section has the literature review of FDI in relation to the topic based on empirical evidence from several countries. The third section provides the description of data and research methods, while the fourth section presents the estimated results and discussion. The final section comprises on conclusions and recommendations for further research and for decision makers.

\section{Literature Review}

The inefficiency of institutions engaged in regulation activities may be connected with the level of corruption and inflow of FDI, hence the suspicious raise not only in insiders but also in the foreign investors (Devine, 2007). Several authors investigated the role of FDI inflow within the framework of macroeconomic stabilization, finding out that a country-cyclical fiscal policy associated with lower tax burden contributed to the fall of output volatility, i.e., positively influenced the macroeconomic stabilization, while FDI do not impact macroeconomic stabilization directly (Albulescu \& lanc, 2016). Conditions for attracting FDI into developing economies appear to be similar for all developing countries. An extreme example may be India, in relation to the study of Lokesha and Leelavathy (2012) where the authors argue that FDI inflow is determined by the 
market size, policy framework, economic stability and factors, and political factors. Mateev and Tsekov (2012) argue that the most important factor in attracting FDI in Eastern European region and Western EU countries is the quality of institutions, while Goodspeed, Martinez-Vasquez, and Zhang (2009) argue that in developing countries this factor is the improvement of the governmental institutions and the public infrastructure.

From the growth point of view, an interesting statement is provided by Nonnenberg and Mendosa (2004) who argue that the GDP growth induces the FDI inflow, while FDI inflow does not necessarily induce the GDP growth. The statement explains that in developing economies FDI does not necessarily enhance the economic growth, a situation one could partially observe in Serbia. Similarly, in the presence of an adequate capital market model, the host country with weak currency attracts more FDI. The reason lies in the depreciation effects of the currency, which makes the assets of the host country less expensive than in the home country of the investor (Froot \& Stein, 1991). Alfaro (2003) claims that FDI are able to provide growth only if the country has sufficiently developed financial markets. Alfaro and Charlton (2007) claim that the type of FDI that have a most economically positive impact on the GDP is FDI in the industry. Industries with higher value added have an advantage in attracting FDI, for example higher skill requirements. Graham and Wada (2002) analysed the relationship between FDI and Chinese economic growth and thus found that FDI were able to increase the productivity of production factors only in case when these investments thrived.

In presenting the opposite attitude, Hanic, Kalicanin and Bodroza (2017), applying the Keynesian model and consequently the multiple Linear Regression Model, explained the relationship between economic growth and economic variables in the period 1999-2015, and proved that FDI in Serbia were not statistically significant for the economic growth. Even though, the exchange rate and inflation rate are statistically significant, i.e., these two factors contribute to predicting of the real GDP growth rate. The authors explain that FDI inflow has no influence on the GDP because Serbia is a country in transition, as well as because of inefficient investments, external debt, and structure of FDI inflow. With respect to government policies, many authors, among them Barro (1996), argue that the growth rate of the real GDP per capita is possible through the viable rule of law, lower government consumption and lower inflation.

Diaconu (2016) analysed several studies regarding the impact of FDI in the EU countries, and found out that the human capital $(\mathrm{HC})$ belonged to the most important variables in determining the FDI inflow. Examining the statistical information, Diaconu (2016) also found that $\mathrm{HC}$ was the fast growing factor which investors look for, i.e., Pearson correlation coefficient $r=0.3$ (2012) grew to almost $r=0.5$ (2014) for $\mathrm{HCl}$ and FDI, confirming that education and skills and abilities of $\mathrm{HC}$ would become the most important variables for attracting FDI. Addison and Heshmati (2003) demonstrate that in the EU countries the factors of $\mathrm{HC}$ and efficiency of institutions have to be taken as determinants of FDI inflow, which is a partial confirmation of Noorbakhsh, Paloni, and Youssef (2001). While Chidlow, Salciuviene and Young (2009) added geographical and political implications to the previous authors, Botric and Skuflic (2006) stressed that the availability of skilled labour force, privatization process, infrastructure and agglomeration factor and trade regime are also important for attracting FDI Inflow.

According to UNCTAD (1994), the liberalization of FDI regimes, privatization programs and rapid growth of developing countries have been the most important reasons to attract FDI, while according to UNCTAD (2002), the level of HC and investments in human resources (HR) appear to be significant factors for attracting FDI. Through the statistical methods, Nunnenkamp and Spatz (2002) confirms that investments in HR bring the higher value added and their effects grow over time. UNCTAD (2010) claims that FDI inflow recorded a rapid decline worldwide from 2007 to 2009 due to the world financial crisis, i.e., it had the negative impact on inward FDI in all sectors and forms of FDI in all regions in the world.

Stojadinovic and Todorovic (2014) affirm that positive effects of FDI inflow in Serbia on employment are not significant. Rakita and Markovic (2013) partially agree with the above cited authors, claiming that the consequences of FDI in Serbia are the increase in real wages and productivity as well as the fall in employment. Similarly, according to Zdravkovic, Duric, and Bradic (2017), the long term effect of FDI on employment in transition countries seems to be very low or even non existent. When measuring the correlation between FDI inflow and unemployment rate for 2000-2014, Parezanin, Jednak, and Kragulj (2016) found out a very low positive correlation, but when splitting the period due to the effects of the global crises, two interesting results came out: in the period 2000-2007 there was a high positive correlation $(r=0.755)$, while in 2008-2014 there was almost no correlation $(r=-0.340)$.

Regarding the relationship between FDI inflow and employment in Serbia, Petrovic and Cerovic (2011) stress out that when mergers and acquisitions occur, FDI inflow does not lead to the increase in the working force, on the contrary, it may lead to the decrease of employment in the initial period. The impact of FDI on wages and employment was also the subject of study of Zhao (1998), affirming that FDI reduces the negotiated 
wages as well as employment in a situation where dying unions take care of the management of labour and wages in the industry sector. Although Radojevic et al. (2015) stress the advantages of Serbia for foreign investors and its real capabilities to attract FDI, it appears that FDI inflow does not have a significant impact on employment and average wage in this country, which corroborates the findings of this research. Also, this paper is a partial confirmation of the recent findings of Rapaic (2017), who studied the correlation between the indicators of economic growth and FDI inflow and confirmed that FDI inflow in Serbia did not decrease the unemployment rate and did not have a significant impact on the employment growth.

During the period under consideration, the unemployment rate in Serbia followed the rising trend, with a decrease in value usually in the year in which some elections occurred. For example, the unemployment rate was 18.1 per cent in 2007 against 13.6 per cent in 2008, then increasing again up to 23.9 per cent in 2012 (Statistical Office of Serbia, 2017). From 2013, the unemployment rate follows the decreasing trend.

As far as the methodology is concerned, this paper's methodology finds similar application in the worldwide literature. Taylor and Driffield (2005) applied the regression model with lagged dependent variable whose results suggest that technology, brought by multinational enterprises, and in particular trade (import), significantly impacts the wage dispersion in the UK. In other words, FDI inward affects the wage dispersion, especially because of the technology spillover in favour of skilled labour force, while in a previous study conducted by Hubert and Pain (2001), FDI inward only appears to increase the labour force, reducing the demand for unskilled labour force. Analysing the relationship between FDI inward and wage inequality in developed and in developing countries, Figini and Gorg (2006), by imposing the lag structure to FDI variables in relationship to the Gini Index, have found that FDI inward stock decreases wage inequality in developed economies, while FDI inward increases wage inequality in developing economies.

Despite the growing research in the FDI field, the scientific literature on average wage and on employment is still limited in relation to FDI inflow in Serbia. To conclude the literature review, one can see that FDI inflow is one of the crucial factors as regards changes in $\mathrm{HC}$, but the question that arises is whether it brings any significant changes in average wage in Serbia. Despite the differences in outcomes, most of the empirical studies confirm that FDI tendentiously increases the economic growth rates, as for example Alfaro and Charlton (2007), but differently in developed and in developing countries.

\section{Research Methodology}

This section presents the quantitative variables, the description of data used for analysis, the statement of hypothesis, and the specification of the chosen statistical models.

The efficient application of the regression model is present in Taylor and Driffield (2005) who use lagged terms, and in Hanic et al. (2017). The econometric model used in this paper is the Linear Regression Model, chosen in order to estimate the relationship between dependent variables and the independent variable, given the short time period and annual data.

The author's intention is to estimate the dependency between the FDI inflow and average wage, and the dependency between the FDI inflow and employment, both in the period 2005-2017.

The data for the quantitative analysis are obtained from the secondary sources, i.e., from the official site of the National Bank of Serbia (2017) for FDI inflow, and from the official site of the Statistical Office of Serbia (2017) for average wage and for employment. Table 1 brings the description of the variables used for this research.

Table 1: Description of variables

\begin{tabular}{|l|l|}
\hline FDI_inflow & $\begin{array}{l}\text { net FDI inflow made to benefit the business interests of the foreign investor in the } \\
\text { host country (Serbia), per period in million euros, in current prices }\end{array}$ \\
\hline AV.WAGE & average net wage per period in euros, in current prices \\
\hline EMPLOY_rate & employment rate calculated on the number of employees per period in thousands \\
\hline YEAR & theoretical assumption of the annual basis effect \\
\hline
\end{tabular}

Source: Author's calculation 
The dependent variables are Average Wage (AV.WAGE) and Employment (EMPLOY_rate\%) modelled in two separate models. The independent variables are the time effect (YEAR) and FDI inflow (FDI_inflow) with its time lags - 3 years - for both models. The lagged terms are used because of the theoretical reasoning that the FDI inflow requires time to show the real effects on average wage (AV.WAGE) and on employment (EMPLOY_rate\%) in the country. Table 2 shows the descriptive statistics of the variables used in this research.

Table 2: Descriptive statistics

Descriptive Statistics

\begin{tabular}{|c|c|c|c|c|c|c|c|c|}
\hline & $\bar{N}$ & Range & Minimum & Maximum & & & Std. Deviation & Variance \\
\hline & Statistic & Statistic & Statistic & Statistic & Statistic & Std. Error & Statistic & Statistic \\
\hline Year & 13 & 12 & 2005 & 2017 & 2011.00 & 1.080 & 3.894 & 15.167 \\
\hline FDI_inflow & 13 & 3314.67 & 1008.81 & 4323.48 & 2255.5646 & 273.94514 & 987.72326 & 975597.243 \\
\hline FDI_inflow_chng\% & 12 & 3.03 & -.72 & 2.32 & .2885 & .25851 & .89552 & .802 \\
\hline FDI_inflow_chng\%_lag1 & 11 & 3.03 & -.72 & 2.32 & .2969 & .28304 & .93873 & .881 \\
\hline FDI_inflow_chng\%_lag2 & 10 & 3.03 & -.72 & 2.32 & .3260 & .31125 & .98427 & .969 \\
\hline FDI_inflow_chng\%_lag3 & 9 & 3.03 & -.72 & 2.32 & .3167 & .34784 & 1.04352 & 1.089 \\
\hline EMPLOY_rate\% & 13 & .11 & .76 & .87 & .8131 & .00960 & .03463 & .001 \\
\hline EMPLOY_rate\%_chng\% & 12 & .10 & -.05 & .05 & .0083 & .00946 & .03278 & .001 \\
\hline AV.WAGE & 13 & 190.75 & 209.75 & 400.50 & 347.4084 & 15.18380 & 54.74596 & 2997.120 \\
\hline AV.WAGE_chng\% & 12 & .49 & -.16 & .34 & .0618 & .03884 & .13456 & .018 \\
\hline Valid N (listwise) & 9 & & & & & & & \\
\hline
\end{tabular}

Source: Author's calculation

Table 2 presents the fundamental information about variables used for modelling. During the period 20052017, the highest amount of the inflow of FDI in Serbia was $€ 4.3$ billion, while the average wage for the country reached $€ 400$, both in real value. With regard to employment, one can see both positive and negative variations during the period of 13 years.

The changes in annual percentages (chng_\%) are used instead of absolute values as units of measure. Since this research aims to explain the rate of change of average wage (AV.WAGE_chng\%) and the rate of change in employment (EMPLOY_rate\%_chng\%) in relation to the changes in FDI inflow (FDI_inflow_chng\%, FDI_inflow_chng\%_lag1, FDI_inflow_chng\%_lag2, FDI_inflow_chng\%_lag3) and consequently compare the results, the multiple Linear Régression Modèls have been uséd.

The author predicts the rate of change in average wage (1) and the rate of change in employment (2), after taking into account the level of FDI inflow, intended to determine whether there is a quantitative relation between FDI inflow and average wage, in the first case, and between FDI inflow and employment in the second case.

The null hypothesis is that there is no impact of FDI inflow on average wage nor on employment, while the alternative hypothesis is that there is an impact of FDI inflow on both average wage and employment. The specification of the empirical models is as follows:

$$
\begin{aligned}
& \% \Delta A V . W A G E_{t}=\alpha+\beta_{1} \text { YEAR }_{t}+\beta_{2} \% \Delta \text { FDI_Inflow } \\
& \beta_{5} \% \Delta \text { FDI_Inflow } \\
& t-3+\varepsilon_{t} \% \Delta \text { FDI_Inflow } \\
& \text { t-1 }
\end{aligned}
$$

Where:

$\alpha$ - intercept of the equation,

$\beta_{n}$ - coefficients with predictors of regression,

$\varepsilon_{\mathrm{t}}-$ residuals of the models.

For the estimation of the models, the IBM SPSS software version 23 has been applied. 


\section{Empirical Results and Discussion}

In order to be certain that FDI inflow with its time lags, one that the models understand as many different variables, will produce credible results, it is important to check the collinearity between them, before proceeding with the modelling and results interpretation. The collinearity diagnostics are presented in the Table 3 and in the Table 4.

Table 3: Collinearity for average wage \% change

Collinearity Diagnostics ${ }^{\mathrm{a}}$

\begin{tabular}{|c|c|c|c|c|c|c|c|c|c|}
\hline \multirow[b]{2}{*}{ Model } & \multirow[b]{2}{*}{ Dimension } & \multirow[b]{2}{*}{ Eigenvalue } & \multirow[b]{2}{*}{$\begin{array}{c}\text { Condition } \\
\text { Index }\end{array}$} & \multicolumn{6}{|c|}{ Variance Proportions } \\
\hline & & & & (Constant) & Year & $\begin{array}{c}\text { FDI_inflow_c } \\
\text { hng\% }\end{array}$ & $\begin{array}{l}\text { FDI_inflow_c } \\
\text { hng\%_lag1 }\end{array}$ & $\begin{array}{c}\text { FDI_inflow_c } \\
\text { hng\%_lag2 }\end{array}$ & $\begin{array}{l}\text { FDI_inflow_c } \\
\text { hng\%_lag3 }\end{array}$ \\
\hline \multirow[t]{6}{*}{1} & 1 & 2.255 & 1.000 & .00 & .00 & .01 & .00 & .00 & .02 \\
\hline & 2 & 2.045 & 1.050 & .00 & .00 & .06 & .05 & .06 & .03 \\
\hline & 3 & .928 & 1.559 & .00 & .00 & .06 & .09 & .05 & .25 \\
\hline & 4 & .617 & 1.912 & .00 & .00 & .34 & .05 & .18 & .14 \\
\hline & 5 & .156 & 3.808 & .00 & .00 & .49 & .68 & .58 & .55 \\
\hline & 6 & $6.440 \mathrm{E}-7$ & 1871.185 & 1.00 & 1.00 & .04 & .13 & .13 & .00 \\
\hline
\end{tabular}

a. Dependent Variable: AV.WAGE_chng\%

Source: Author's calculation

Table 4: Collinearity for employment rate \% change

Collinearity Diagnostics ${ }^{a}$

\begin{tabular}{|c|c|c|c|c|c|c|c|c|c|}
\hline \multirow[b]{2}{*}{ Model } & \multirow[b]{2}{*}{ Dimension } & \multirow[b]{2}{*}{ Eigenvalue } & \multirow[b]{2}{*}{$\begin{array}{l}\text { Condition } \\
\text { Index }\end{array}$} & \multicolumn{6}{|c|}{ Variance Proportions } \\
\hline & & & & (Constant) & Year & FDI_inflow_c & $\begin{array}{c}\text { FDI_inflow_c } \\
\text { hng\%_lag1 }\end{array}$ & $\begin{array}{c}\text { FDI_inflow_c } \\
\text { hng\%_lag2 }\end{array}$ & $\begin{array}{c}\text { FDI_inflow_c } \\
\text { hng\%_lag3 }\end{array}$ \\
\hline \multirow[t]{6}{*}{1} & 1 & 2.255 & 1.000 & .00 & .00 & .01 & .00 & .00 & .02 \\
\hline & $\underline{2}$ & 2.045 & 1.050 & 00 & 00 & 06 & 05 & 06 & 03 \\
\hline & 3 & .928 & 1.559 & .00 & .00 & .06 & .09 & .05 & .25 \\
\hline & 4 & .617 & 1.912 & .00 & .00 & .34 & .05 & .18 & .14 \\
\hline & 5 & .156 & 3.808 & .00 & .00 & .49 & .68 & .58 & .55 \\
\hline & 6 & $6.44 \mathrm{DE}-7$ & 1871.185 & 1.00 & 1.00 & .04 & .13 & .13 & مِ \\
\hline
\end{tabular}

a. Dependent Variable: EMPLOY_rate\%_chng\%

Source: Author's calculation

The diagnostics of collinearity, according to Tables 3 and 4, have shown low degrees of the condition index and variance proportions, therefore the research is to proceed with modelling and results interpretation.

Taking into account only the change in FDI inflow (FDI_inflow_chng\%), the model fails to present reliable results for discussion. Adding one by one lag, both models shave howed reliable results with the third lag (FDI_inflow_chng\%_lag3). By adding more lags, the models get exhausted because of the lack of official national data, and also because they follow the logic that some primary results of FDI inflow would be felt after a few years. Therefore, Table 5 and Table 6 present the models.

Table 5: Estimated model 1 coefficients

Coefficients $^{\mathbf{a}}$

\begin{tabular}{|c|c|c|c|c|c|c|c|c|}
\hline \multirow[b]{2}{*}{ Model } & & \multicolumn{2}{|c|}{ Unstandardized Coefficients } & \multirow{2}{*}{$\begin{array}{c}\begin{array}{c}\text { Standardized } \\
\text { Coefficients }\end{array} \\
\text { Beta }\end{array}$} & \multirow[b]{2}{*}{$t$} & \multirow[b]{2}{*}{ Sig. } & \multicolumn{2}{|c|}{ Collinearity Statistics } \\
\hline & & $B$ & Std. Error & & & & Tolerance & VIF \\
\hline 1 & (Constant) & -12.215 & 18.879 & & -.647 & .564 & & \\
\hline & Year & .006 & .009 & .207 & .647 & .564 & .783 & 1.278 \\
\hline & FDI_inflow_chng\% & .076 & .044 & .674 & 1.707 & .186 & .514 & 1.945 \\
\hline & FDI_inflow_chng\%_lag1 & .018 & .055 & .158 & .321 & .769 & .329 & 3.039 \\
\hline & FDI_inflow_chng\%_lag2 & .000 & .051 & -.003 & -.007 & .995 & .377 & 2.656 \\
\hline & FDI_inflow_chng\%_lag3 & -.031 & .029 & -.404 & -1.079 & .359 & .573 & 1.745 \\
\hline
\end{tabular}

a. Dependent Variable: AV.WAGE_chng\% 
Table 6: Estimated model 2 coefficients Coefficients $^{\mathbf{a}}$

\begin{tabular}{|c|c|c|c|c|c|c|c|c|}
\hline \multirow[b]{2}{*}{ Model } & & \multicolumn{2}{|c|}{ Unstandardized Coefficients } & \multirow{2}{*}{$\begin{array}{c}\begin{array}{c}\text { Standardized } \\
\text { Coefficients }\end{array} \\
\text { Beta }\end{array}$} & \multirow[b]{2}{*}{$\mathrm{t}$} & \multirow[b]{2}{*}{ Sig. } & \multicolumn{2}{|c|}{ Collinearity Statistics } \\
\hline & & $\mathrm{B}$ & Std. Error & & & & Tolerance & VIF \\
\hline \multirow[t]{6}{*}{1} & (Constant) & -19.630 & 4.864 & & -4.036 & .027 & & \\
\hline & Year & 010 & 002 & 826 & 4.033 & 027 & 783 & 1.278 \\
\hline & FDI_inflow_chng\% & -.005 & .011 & -.116 & -.460 & .677 & .514 & 1.945 \\
\hline & FDI_inflow_chng\%_lag1 & .008 & .014 & .171 & .541 & .626 & .329 & 3.039 \\
\hline & FDI_inflow_chng\%_lag2 & .020 & .013 & .457 & 1.547 & .220 & .377 & 2.656 \\
\hline & FD!_inf!now_chnng\%_!aņ3 & .014 & .007 & .438 & 1.828 & .165 & .573 & 1.745 \\
\hline
\end{tabular}

a. Dependent Variable: EMPLOY_rate\%_chng\%

Source: Author's calculation

In observing the models, the dependent variables change in the time $t$ by certain percentage points, after taking into consideration the level of FDI Inflow in that year and in previous periods.

According to model 1 in Table 5, the double increase in FDI inflow tends to increase the rate of change in average wage (AV.WAGE_chng_\%) by only 7.6 percentage points in the year FDI inflow occurs (FDI_inflow_chng\%); after a while there is a very low impact of FDI inflow on average wage in the country, with the work-shy increasing trend. According to model 2 in Table 6 , there will be a poor increase in the rate of change in employment (EMPLOY_rate\%_chng\%) after 2 years (FDI_inflow_chng\%_lag2), namely, only 2 percentage points due to the double change in FDI inflow. Therefore, the null hypotheses is rejected, with the emphases that the models do not show statistical significance in the FDI inflow impact on dependent variables. Only the time effect (YEAR) appears significant $(p=0.027)$, which is in line with the theoretical assumption that FDI inflow needs time to present its first positive effects on employment.

The highest (even if very low) positive spillover effect of the FDI inflow on dependent variables, starting from the moment the direct investments occur, is in the year $t$ of FDI inflow for average wage and in the second year $t-2$ for employment. Therefore, the increase in employment does not match the increase in average wage in the time. The results of the regression analysis confirmed the hypothesis that the FDI inflow does not contribute in a significant way to the increase in average wage and employment in the period under consideration. Moreover, the FDI inflow appears responsible for the decrease in average wage and employment, after 3 years $(t-3)$ and in the year $(t)$ the FDI inflow occurs, respectively.

Additionally, according to this research, the FDI inflow produces some increase in average wage in the same year it occurs, mostly because the foreign investor brings its management into the country, thus adjusting the national accounts. As seen before, when mergers and acquisitions occur, in theory they lead to the decrease in employment in the initial period, while in the long-term period a positive effect of FDI inflow on employment is expected. Moreover, the researchers' investigation into foreign investors in Serbia is limited, since information about subsidiaries and grants given to the foreign investors are not publicly available.

\section{Conclusions and Recommendations}

This research aimed to estimate the impact of FDI inflow on average wage and employment in Serbia in the period 20052017. Through Multiple Linear Regression Models, this research has confirmed that the FDI inflow gives a minimum contribution in increasing average wage and employment, while the time effect plays the main role in showing positive impact of FDI inflow on employment. With regard to the average wage, there is barely an increase, which is not statistically significant and which proves to be meaningless for families. The research has proven that FDI inflow has no significant impact on variables, as the main indicators of the welfare of the population.

In observing the trends of indicators, one can see the common phenomenon for the countries in transition, i.e., a very slight decrease in unemployment, which in Serbia officially was 14.7 per cent at the end of 2017, undoubtedly a high value and sign of a weak country's economy (Statistical Office of Serbia, 2017). The challenge for Serbia is to improve the performance of FDI by knowing that FDI inflow could potentially become an efficient investment if policy-makers establish rules to benefit Serbian market itself, if corruption is significantly reduced, if investments are more directed into the sector of industry, and if foreign investors respect the rules of the host country. In order for Serbia to benefit more efficiently from FDI inflow, in particular in the field of average wage and employment growth, the author assumes that the transparent institutional environment and the rule of law is essential. 
The conclusion is that FDI inflow has a low and statistically not significant impact on average wage and employment in Serbia during the period from 2005 to 2017, that is in line with the findings of Stojadinovic and Todorovic (2014), Radojevic et al. (2015), and Hanic et al. (2017).

The awareness of limitations of this study is what the author has left for further research. The first limitation is the unavailability of FDI official national data. The second limitation is that only one country is taken into consideration. And the third limitation is the inclusion of just three macroeconomic indicators.

\section{REFERENCES}

[1] Addison, T. \&Heshmati, A. (2003). The new global determinants of FDI flows to developing countries: The importance of ICT and democratization. Research in Banking and Finance, 4, 151-186. DOI:10.1016/S1567-7915(04)04007-8

[2] Albulescu, C. T. \&lanc, N. B. (2016). Fiscal policy, FDI and macroeconomic stabilization. Review of Economic and Business Studies, 9(2), 131-146. DOI:10.1515/rebs-2016-0038

[3] Alfaro, L. (2003). Foreign Direct Investment and Growth: Does the sector Matter? Harvard Business School, 1-31.

[4] Alfaro, L. \& Charlton, A. (2007). Growth and the quality of Foreign Direct Investment: Is all FDI equal (HBS Finance Working Paper No. 07-072). DOI:10.2139/ssrn.981163

[5] Barro, R. (1996). Determinants of economic growth: A cross-country empirical study. National Bureau of Economic Research (NBER Working Paper No. 5698).DOI:10.3386/w5698

[6] Bartels, F. L. (2009). FDI Policy Instruments: Advantages and Disadvantages(UNIDO Working Paper 01/2009). Retrieved from link: http://www.waipa.org/wp-content/uploads/2016/07/UNIDO_FDI-PolicyInstruments-Advantages-and-Disadvantages.pdf

[7] Botric, V. \&Skuflic, L. (2006). Main Determinants of Foreign Direct Investment in the Southeast European Countries. Transition Studies Review, 13(2), 359-377.DOI:10.1007/s11300-006-0110-3

[8] Chidlow, A. Salciuviene, L. \& Young, S. (2009). Regional determinants of inward FDI distribution in Poland. International Business Review, 18(2), 119-133.DOI:10.1016/j.ibusrev.2009.02.004

[9] Devine, V. (2007). Corruption and doing business in Serbia. Chr. Michelsen Institute, Oslo (11), 1-4. Retrieved from link:https://www.u4.no/publications/corruption-and-doing-business-in-serbia/pdf

[10] Diaconu, L. (2016). Is Human Capital a Major Determinant of the FDI Inflow? Empirical evidences from the EU states(CES Working Papers). Retrieved from link: https://ideas.repec.org/a/jes/wpaper/y2016v8i2p238-250.html

[11] Figini, P. \&Gorg, H. (2006). Does foreign direct investment affect wage inequality? An empirical investigation(IZA Discussion paper No. 2336). Retrieved from link:http://hdl.handle.net/10419/4015

[12] Froot, K. A. \& Stein, J. C. (1991). Exchange Rate and Foreign Direct Investment: An imperfect capital markets approach. The Quarterly Journal of Economics, 106(4), 1191-1217.DOI:10.2307/2937961

[13] Goodspeed, T., Martinez-Vasquez, J. \& Zhang, L. (2009). Public Policies and FDI Location: Differences between Developing and Developed Countries, FinanzArchiv/Public Finance Analysis, 67(2), 171-191.

[14] Graham, M. E. \& Wada, E. (2002). Foreign Direct Investment in China: Effects on growth and economic performance(Institute for International Economics Working Paper No. 01-03).Retrieved from link: https://papers.ssrn.com/sol3/papers.cfm?abstract_id $=300884$

[15] Hanic H., Kalicanin T., \&Bodroza D. (2017). Comparative analysis of the influence of FDI Inflow on economic development between Serbia and Poland(Institute of Economic Research Working papers No. 43/2017). Retrieved from link:https://ideas.repec.org/p/pes/wpaper/2017no43.html

[16] Hubert, F. \& Pain, N. (2001). Inward investment and technological progress in the UK. In: Pain N. (eds) Inward Investment Technological Change and Growth (pp. 66-103). Palgrave Macmillan, London.

[17] Javorcik, B. S. (2015). Does FDI bring good jobs to host countries? World Bank Research Observer, 30(1), 74-94.

[18] Lokesha, B. K. \&Leelavathy, D. S. (2012). Determinants of Foreign Direct Investments: a Macro Perspective. Indian Journal of Industrial Relations, 47(3), 459-469.

[19] Mateev, M. I. \&Tsekov, I. (2012). Do Central and Western European Countries Posses FDI Advantages to More Developed Western Countries? Retrieved from link: http://ssrn.com/abstract?=2139361

[20] Ministry of Economy, Republic of Serbia. (2018).Privatization. Retrieved from link: http://www.priv.rs/Ministry-of-Economy/211/Privatization.shtml

[21] National Bank of Serbia. (2017).Statistics. Retrieved from link:https://www.nbs.rs/internet/english/80/index.html\#eoi

[22] Nonnenberg, M. \&Mendosa, M. (2004). The determinants of direct foreign investment in developing countries. Proceedings of the $32^{\text {th }}$ Brazilian Economics Meeting. Retrieved from link: https://papers.ssrn.com/sol3/papers.cfm?abstract_id $=525462$ 
[23] Nunnenkamp, P. \&Spatz, J. (2002). Determinants of FDI in Developing Countries: Has Globalization Changed the Rules of the Game? Transitional Corporation, 11(2), 1-34.

[24] Noorbakhsh, F., Paloni, A. \& Youssef, A. (2001). Human Capital andFDI Inflow to Developing Countries: New Empirical Evidence. World Development, 29(9), 1593-1610.DOI:10.1016/S0305-750X(01)00054-7

[25] Parezanin, M., Jednak, S. \&Kragulj, D. (2016). The Impact of FDI on the Economic Growth of Serbia. Management, 21(78), 25-32. DOI:10.7595/management.fon.2016.0003

[26] Peric, M. (2016). Brazilian Economy in the $21^{\text {st }}$ century. Economic performance from the Second Republic to nowadays. Edizioni Academiche Italiane, Germany.

[27] Peric, M \&Filipovic, S. (2018). Impact of export determinants on the export sector in Republic of Serbia, Industrija, 46(2), 151-171.

[28] Petrovic, P. \&Cerovic, S. (2011). The Characteristics of Foreign Direct Investments in Serbia. Journal of Knowledge Management, Economics and Information Technology, 1(6), 1-12.

[29] Radojevic, T., Sarac, M., Radovanovic, D. \&Stanisic, N. (2015). The advantages of Serbia for Foreign Direct Investments. Paper presented at the 19th International Academic Conference, Florence.

[30] Rakita, B. \&Markovic, D. (2013). The effects of international acquisition in Serbia on status and engagement of human resources. Industrija, 41(1), 55-77.DOI: 10.5937/industrija46-17408

[31] Rapaic, S. (2017). The impact of FDI on the economic development in Serbia, Ekonomika preduzeca, 65(5-6), 381-392. DOI:10.5937/EKOPRE1706381R

[32] Staknov, B., Markov, J. \& Milosevic, I. (2015). FDI by economic Activities and Investment Incentives in Bulgaria and Serbia. Management, 20(77), 61-69. DOI:10.7595/management.fon.2015.0026

[33] Statistical Office of Serbia (2017). Labour market. Retrieved from link: http://data.stat.gov.rs/?caller=SDDB\&languageCode =en-US

[34] Stojadinovic, J. S. \&Todorovic, V. (2014). Efekti priliva I odliva stranog kapitala na zaposlenost. Ekonomski vidici, 19(2-3), 141-155.

[35] Telenor Group (2006, July 31 ${ }^{\text {st }}$ ). Telenor acquires Mobi 63 in Serbia. Retrieved from link: https://www.telenor.com/media/press-release/telenor-acquires-mobi-63-in-serbia

[36] UNCTAD (1994). World Investment Report, New York and Geneva.

[37] UNCTAD (2002). World Investment Report, New York and Geneva.

[38] UNCTAD (2007). World Investment Report, New York and Geneva.

[39] UNCTAD (2010). World Investment Report, New York and Geneva.

[40] UNCTAD (2013). World Investment Report, New York and Geneva.

[41] UNCTAD (2017a). Foreign direct investments. Handbook of statistics, December 2017.

[42] UNCTAD (2017b). World Investment Report, New York and Geneva (Transition Economies).

[43] Taylor, K. \&Driffield, N. (2005). Wage inequality (dispersion) and the role of multinationals: Evidence from UK panel data.Labour Economics, 12(2), 223-249. DOI: 10.1016/j.labeco.2003.11.003

[44] Zdravkovic, A., Duric, M. and Bradic, M. A. (2017). Uticaj stranih direktnih investicija na nezaposlenost u tranzicionim zemljama - kointegraciona analiza panela. Industrija, 45(1), 161-174.

[45] Zhao, L. (1998). The impact of foreign direct investment on wages and employment. Oxford economic papers, 50(2), 284-301.DOI:10.1093/oxfordjournals.oep.a028646

Received: 2018-06-26

Revisions requested: 2018-08-30

Revised: 2018-12-19 (2 times)

Accepted: 2019-02-09

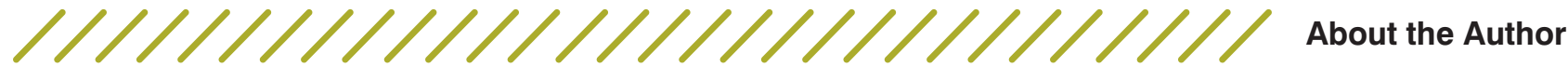

\section{Milica Perić \\ Singidunum University, Belgrade, Serbia e-mail: milicamip@gmail.com}

Milica Peric is a PhD student at the Singidunum University enrolled in Conteporary Business Decision Making. Milica's area of research is finance and banking, with the focus on the national economic development and movement of foreign capital. Graduated in Economy and management, and International bussines and development, Milica collaborated in numerous international

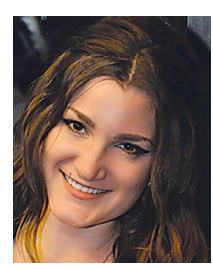
projects in Italy, Portugal, Cyprus and Brazil. 


\section{Annex 1 Model summary}

Table 1a. Model summary for (1)

Model Summary

\begin{tabular}{llrrr}
\hline \hline Model & $\mathrm{R}$ & $\mathrm{R}$ Square & $\begin{array}{c}\text { Adjusted } \mathrm{R} \\
\text { Square }\end{array}$ & \multicolumn{1}{c}{$\begin{array}{c}\text { Std. Error of } \\
\text { the Estimate }\end{array}$} \\
\hline 1 & $.872^{\mathrm{a}}$ & .760 & .359 & .06429 \\
\hline \hline
\end{tabular}

a. Predictors: (Constant), FDI_inflow_chng\%_lag3,

FDI_inflow_chng\%_lag1, Year, FDI_inflow_chng\%,

FDI_inflow_chng\%_lag2

Table 1b. Model summary for (2)

\section{Model Summary}

\begin{tabular}{llrrr}
\hline \hline Model & $\mathrm{R}$ & R Square & $\begin{array}{c}\text { Adjusted } \\
\text { Square }\end{array}$ & $\begin{array}{l}\text { Std. Error of } \\
\text { the Estimate }\end{array}$ \\
\hline 1 & $.949^{\mathrm{a}}$ & .901 & .737 & .01656 \\
\hline \hline
\end{tabular}

a. Predictors: (Constant), FDI_inflow_chng\%_lag3,

FDI_inflow_chng\%_lag1, Year, FDI_inflow_chng\%, FDI_inflow_chng\%_lag2

\section{Annex 2 Analysis of variance}

Table 2a. Analysis of variance for (1)

ANOVA ${ }^{a}$

\begin{tabular}{llrrrrr}
\hline \hline Model & & $\begin{array}{c}\text { Sum of } \\
\text { Squares }\end{array}$ & df & Mean Square & F & Sig. \\
\hline 1 & Regression & .039 & 5 & .008 & 1.898 & $.317^{\text {b }}$ \\
& Residual & .012 & 3 & .004 & & \\
& Total & .052 & 8 & & & \\
\hline \hline
\end{tabular}

a. Dependent Variable: AV.WAGE_chng\%

b. Predictors: (Constant), FDI_inflow_chng\%_lag3, FDI_inflow_chng\%_lag1, Year, FDI_inflow_chng\%, FDI_inflow_chng\%_lag2

Table 2b. Analysis of variance for (2)

ANOVA ${ }^{a}$

\begin{tabular}{lllrrrr}
\hline \hline Model & & $\begin{array}{c}\text { Sum of } \\
\text { Squares }\end{array}$ & df & Mean Square & F & Sig. \\
\hline 1 & Regression & .008 & 5 & .002 & 5.491 & $.096^{b}$ \\
& Residual & .001 & 3 & .000 & & \\
& Total & .008 & 8 & & & \\
\hline \hline
\end{tabular}

a. Dependent Variable: EMPLOY_rate\%_chng\%

b. Predictors: (Constant), FDI_inflow_chng\%_lag3, FDI_inflow_chng\%_lag1, Year, FDI_inflow_chng\%,FDI_inflow_chng\%_lag2 